\title{
超高張力鋼板の局部通電加熱穴抜き加工
}

\author{
森 謙一郎 ${ }^{*}$ 藤阪 靖二** 内田 光隆 ${ }^{* * *}$ \\ 上薗 俊 ${ }^{* * *}$ 前野 智美*
}

\section{Punching of Ultra High Strength Steel Sheets Using Local Resistance Heating}

\author{
Ken-ichiro MORI*, Seiji FUZISAKA ${ }^{* *}$, Mitsutaka UCHIDA ${ }^{* * *}$, \\ Shun KAMIZONO*** and Tomoyoshi MAENO*
}

(Received on May 11, 2009)

\begin{abstract}
A punching process using local resistance heating near a circular shearing band was developed to shear ultra high strength steel sheets. The shearing band was heated by the electrification between the sheet holder and the knockout in order to decrease the flow stress in the shearing, and the heating of the die and punch was prevented by eliminating contact with the sheet during the electrification. Electrode pins having a spring were employed to attain uniform heating of the shearing band. The degree of welding of the head of a $\mathrm{Cu}-\mathrm{W}$ electrode pin to the sheet by the electrification was smaller than those of $\mathrm{Ag}-\mathrm{W}, \mathrm{Ag}+\mathrm{WC}$ and $\mathrm{W}$ pins, and thus the $\mathrm{Cu}-\mathrm{W}$ pins were employed in a punching experiment of $980 \mathrm{MPa}$ level ultra high strength steel sheets. The punching load was considerably reduced by the heating, e.g., about $1 / 5$ of the cold load at $800^{\circ} \mathrm{C}$. As the heating temperature increased, the depth of the shiny burnished surface on the sheared edge increased and that of the rough fracture surface decreased.
\end{abstract}

Key words: punching, forming property, ultra high strength steel sheet, local resistance heating, electrode pin, pin material, shearing load, heating temperature.

\section{1. 緒 言}

自動車の燃費向上を目的として自動車の軽量化が望まれ ており, 高張力鋼板の自動車部品への利用が急増しており, $1 \mathrm{GPa}$ を超える超高張力鋼板も適用されつつある ${ }^{1), 2)}$. 超高 張力鋼板は衝突安全性を向上するために自動車ボディの骨 格部材に使用されるようになってきているが, 冷間プレス 成形では加工荷重・スプリングバックの増大, 成形性・金 型寿命の低下，遅れ破壊などが問題となっている.

超高張力鋼板は高強度であるため, プレス成形だけでな く，せん断加工も困難になっている．超高張力鋼板をせん 断加工すると, 加工荷重が増大して金型の寿命低下・破損 などが大きな問題となっている ${ }^{3)}$. 特に, 加工硬化した冷 間成形体やダイクエンチ成形体は非常に高強度であり, 卜 リミングや穴抜き加工が困難であり, 通常レーザ切断が適 用されているが, レーザ切断では生産性が低い.

超高張力鋼板のスプリングバックと延性の問題を解決 するために，温・熱間プレス成形が注目されている ${ }^{4) ~ 8) . ~}$ 板材を加熱することによって, 変形抵抗が減少して成形荷 重, スプリングバックが減少し, 成形性は増加する.さら

\footnotetext{
* 豊橋技術科学大学 $\bar{T} 441-8580$ 豊橋市天伯町雲雀ヶ丘 1-1 Toyohashi University of Technology, 1-1 Hibarigaoka, Tempaku-cho, Toyohashi 441-8580, Japan.

** 豊橋技術科学大学大学院工学研究科 同上 Graduate student, ibid.

*** アイシン精機侏車体生技部 テ448-8650 刈谷市朝日町 2-1 Body Components Production Engineering Department, Aisin Seiki Co., Ltd. 2-1, Asahi-machi, Kariya 448-8650, Japan.
}

に，熱間プレス成形ではダイスによる急冷で焼入れも行う ダイクエンチ法も開発されており, 成形品の引張強さが 1.5GPa にも達している. 一方, 板材のせん断加工は通常冷 間で行われるが，板材を加熱するとせん断荷重は大幅に低 減できる ${ }^{9)}$. 筆者ら ${ }^{10)}$ は超高張力鋼板の通電加熱を用いた 温・熱間せん断加工法を提案しており，せん断荷重が大幅 に低下寸るだけでなく, 高品位な切口面が得られた. 通電 加熱は高い加熱効率を有し，2 秒程度で鋼板を $900^{\circ} \mathrm{C}$ に急 速加熱できプレス機械との同期が可能であり，金型内に設 置できた.しかしながら，板材の両端から通電したため， 矩形の板材しか均一に加熱されなく，成形体に適用するの は困難であった。また，板材全体を加熱したため，エネル ギー効率が低いだけでなく, せん断領域以外も加熱されて 表面品質も低下した.

本研究では, せん断領域に電極を配置して局部通電を行 い，せん断領域付近を加熱してせん断加工を行った．局部 通電加熱に適した電極の材質・形状を調べるとともに，超 高張力鋼板の局部通電加熱穴抜き加工を行って切口面性状, せん断荷重, 組織を求めた。

\section{2. せん断領域局部通電加熱せん断加工法}

超高張力鋼板のせん断加工を容易にするため, 板材を加 熱して変形抵抗を減少させて加工を行う.せん断加工では, せん断される局部領域だけを変形させるため, その領域だ けを加熱することを考え, Fig. 1 に示すようにせん断領域 
だけを通電してジュール熱によって加熱を行う．金型の加 熱を防止するために，通電は板押えとノックアウト間で行 い, 加熱中の板材はダイスとパンチには接触させなく, 通 電終了直後にせん断加工を行う. 通電加熱では, 電流を流 した領域のみが加熱されるため，局部加熱が可能になる. (a) Resistance heating

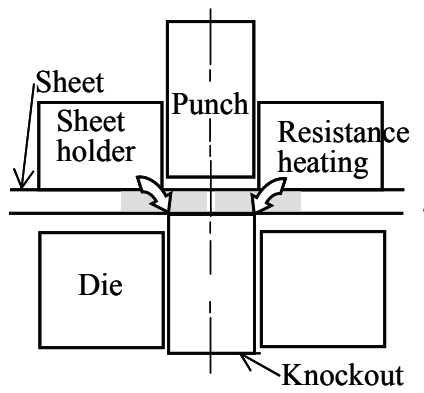

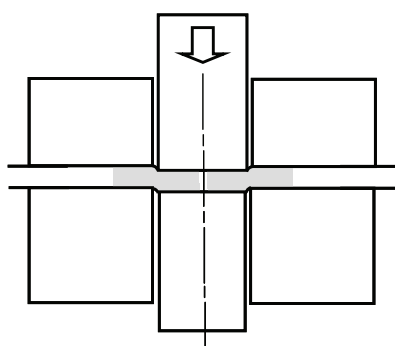

(b) Shearing
Fig. 1 Punching of ultra high strength steel sheets using local resistance heating of circular shearing band

通電加熱では大電流を流すため, 電極と板材の接触が問 題となる. Fig. 2 に示すような円筒状と円柱状一体電極で は不均一接触になりやすく, リング状せん断領域全体が加 熱されない. 不均一接触を生じると接触部分だけに電流が 流れてその部分だけが加熱される.

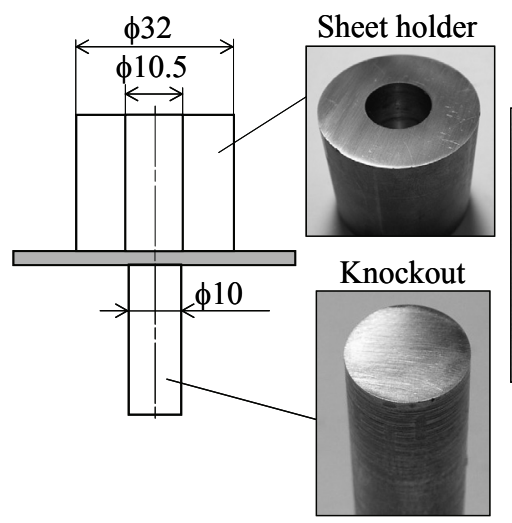

Heated sheet

Fig. 2 Non-uniform heating of shearing band by non-uniform contact with electrodes

不均一接触を防止するために，電極を分割して Fig. 3 に 示すような電極ピンを用いてそれぞれのピンに力を作用さ せ，せん断領域全体を加熱することを考えた．板押えとノ ックアウトに穴を空けてピンを通し，それぞれのピンには バネを付けて均一に接触させる.

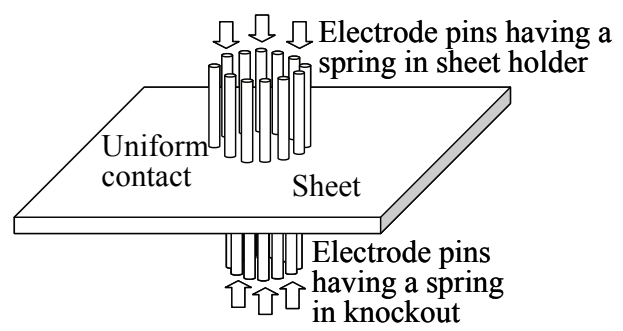

Fig. 3 Electrode pins having a spring for preventing non-uniform contact in local resistance heating

\section{3. 局部通電加熱における電極特性}

\section{1 電極ピン材質による加熱・溶着特性}

電極ピンを用いることによって接触は均一に近づくが, 抵抗溶接に用いられているクロム銅を電極ピンに用いると， Fig. 4 に示すように細いピンに大電流を通すために電極が 鋼板に溶着した.

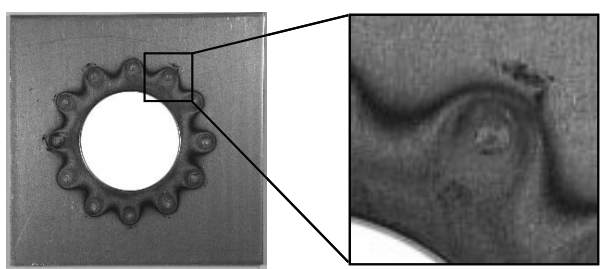

Fig. 4 Welding of head of copper chromium electrode pin to sheet by electrification

電極ピンの溶着を防止するため, 電極材質を変化させて 通電加熱を行って材質の影響を調查した。ノックアウト側 電極は W に固定して板押え側電極を $\mathrm{Ag}-\mathrm{W}, \mathrm{Cu}-\mathrm{W}, \mathrm{Ag}+\mathrm{WC}$, $\mathrm{W}$ に変化させた. 電極ピンの材料定数を Table 1 に示す. 通電加熱では定電流電源を用い，電流を $2.0 \mathrm{kA}$ にして投入 電力量を $4.0 \sim 18.0 \mathrm{~kJ}$ で変化させて加熱温度を制御した. 厚 さ $t=1.4 \mathrm{~mm}$, 長さおよび幅 $50 \mathrm{~mm}$ の引張強さ $980 \mathrm{MP}$ 級超高 張力鋼板 SPFC980Y を電極ピンによって局部加熱した.

Table 1 Material constants of electrode used in local resistance heating

\begin{tabular}{|c|c|c|c|c|}
\hline $\begin{array}{c}\text { Electrode } \\
\text { material }\end{array}$ & $\begin{array}{c}\text { Electrical } \\
\text { resistance } \\
/ \Omega \mathrm{m}\end{array}$ & $\begin{array}{c}\text { Thermal } \\
\text { conductivity } \\
/ \mathrm{W} \cdot \mathrm{m}^{-1} \cdot \mathrm{K}^{-1}\end{array}$ & $\begin{array}{c}\text { Hardness } \\
/ \mathrm{HV} 30\end{array}$ & $\begin{array}{c}\text { Density } \\
/ \mathrm{kg} \cdot \mathrm{m}^{-3}\end{array}$ \\
\hline $\mathrm{Ag}-\mathrm{W}$ & $3.25 \times 10^{-9}$ & 233 & 210 & $14.8 \times 10^{3}$ \\
\hline $\mathrm{Cu}-\mathrm{W}$ & $3.59 \times 10^{-9}$ & 258 & 225 & $14.2 \times 10^{3}$ \\
\hline $\mathrm{Ag}+\mathrm{WC}$ & $4.66 \times 10^{-9}$ & 120 & 250 & $12.8 \times 10^{3}$ \\
\hline $\mathrm{W}$ & $5.56 \times 10^{-9}$ & 200 & 450 & $19.3 \times 10^{3}$ \\
\hline
\end{tabular}

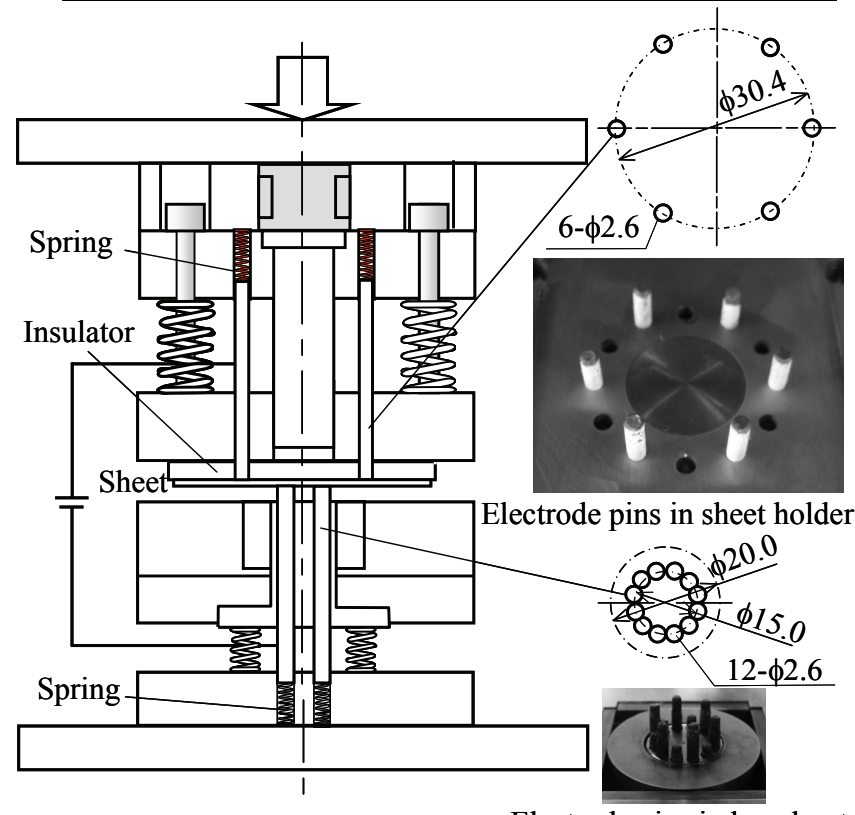

Electrode pins in knockout

Fig. 5 Evaluation of electrode materials for welding of pins in local resistance heating 
電極ピンを用いた局部通電加熱装置を Fig. 5 に示す．電 極ピンはそれぞれスプリングで独立して鋼板に加圧させる ことによって接触を均一にしている. ノックアウト側電極 ピンは 12 本であるのに対して, 板押え側電極ピンは 6 本と して板押え側電極の溶着に対してきびしい条件にした．本 装置では，直径 $20.0 \mathrm{~mm}$ の穴抜き加工を想定しており，板 押え側電極ピンは中心から半径 $15.2 \mathrm{~mm}$, ノックアウト側 電極ピンは中心から半径 $7.5 \mathrm{~mm}$ の位置にそれぞれ配置し た.

せん断領域加熱温度 $T$ に及ぼす電極ピン材質の影響を Fig. 6 に示す. せん断領域加熱温度は, 鋼板上面における 直径 $20.0 \mathrm{~mm}$ の位置 2 箇所に熱電対を取付けて測定された. $\mathrm{Ag}-\mathrm{W}, \mathrm{Cu}-\mathrm{W}, \mathrm{Ag}+\mathrm{WC}, \mathrm{W}$ の順に加熱温度が高く, 加熱 特性としてはすぐれている。これは, Table 1 に示す電気抵 抗率が小さくなって電気が通りやすくなり, 多くの電流が 鋼板に流れるためである.

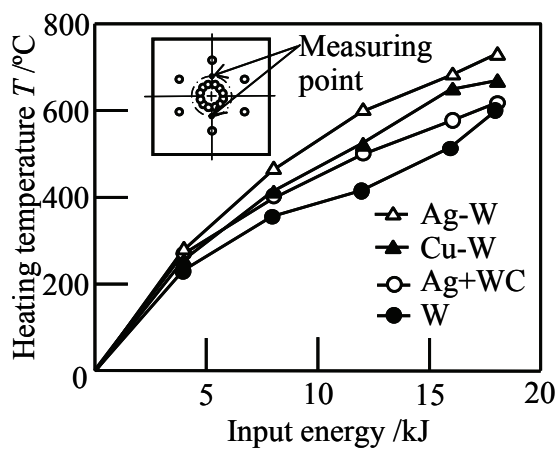

Fig. 6 Effect of electrode material on heating temperature of shearing band

せん断領域加熱温度 $T=800^{\circ} \mathrm{C}$ において, 各種電極によっ て加熱された鋼板の板押え側表面を Fig. 7 に示す。電子線 マイクロアナライザーから鋼板に付着しているのは $\mathrm{W}$ 成 分が昇華したものであることが分り， $\mathrm{Cu}-\mathrm{W}$ が一番少ない 溶着であった。

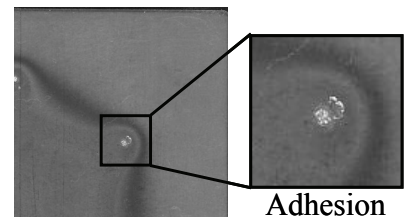

(a) $\mathrm{Ag}-\mathrm{W}$

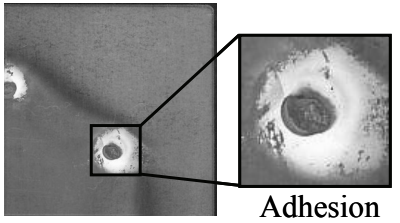

(c) $\mathrm{Ag}+\mathrm{WC}$ of $\mathrm{W}$

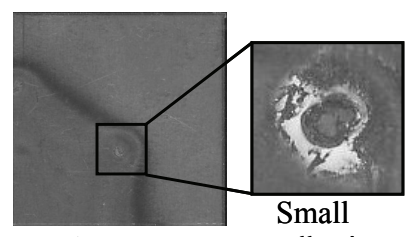

(b) $\mathrm{Cu}-\mathrm{W}$

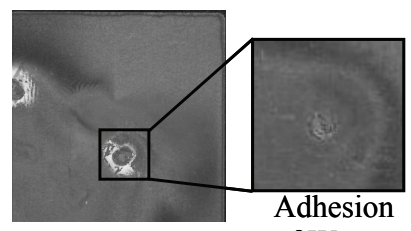

(d) $\mathrm{W}$ of $\mathrm{W}$
Fig. 7 Welding of heads of pins to sheet for $T=800^{\circ} \mathrm{C}$

\section{2 電極形状}

鋼板が厚くなると加熱体積が大きくなり, 電力量も増加 して電気を通す電極の断面積を大きくする必要があるが, 空間的にノックアウト側に電極ピンを用いることができな くなる．そこで，ノックアウト側は電極ピンではなく, Fig. 8 に示すような一体型とし, 接触面は外直径 $19.0 \mathrm{~mm}$, 内直
径 13.0mm のリング状である。一体型電極リングに対して 接触面圧を増加させて接触を安定させるため, 電極リング の接触面積を板押え側電極ピンの全接触面積の $65 \%$ にした. また，板押え側の電極ピンは先端を半径 $60 \mathrm{~mm}$ の球状にし て接触を安定させ，直径 $5.0 \mathrm{~mm}$ のピンを円周方向に 12 本 配置した，特に，高強度である超高張力鋼板では，電極先 端を球状にすることは有効である.
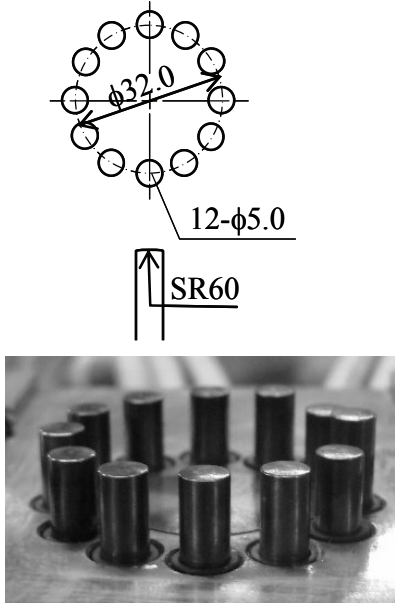

(a) Spherical head electrode pins in sheet holder
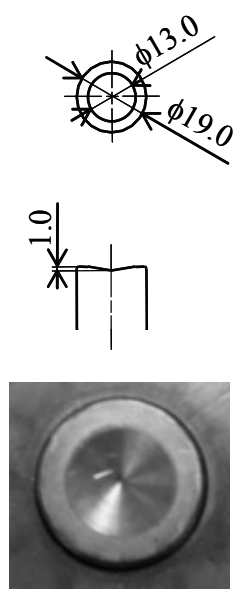

(b) Electrode ring in knockout
Fig. 8 Electrodes in sheet holder and knockout

板押え側先端球状電極ピンとノックアウト側電極リン グを用いた加熱特性を Fig. 9 に示す．板押え側先端丸み付 き電極ピンを用いると，接触が安定して溶着が少なくなっ た.

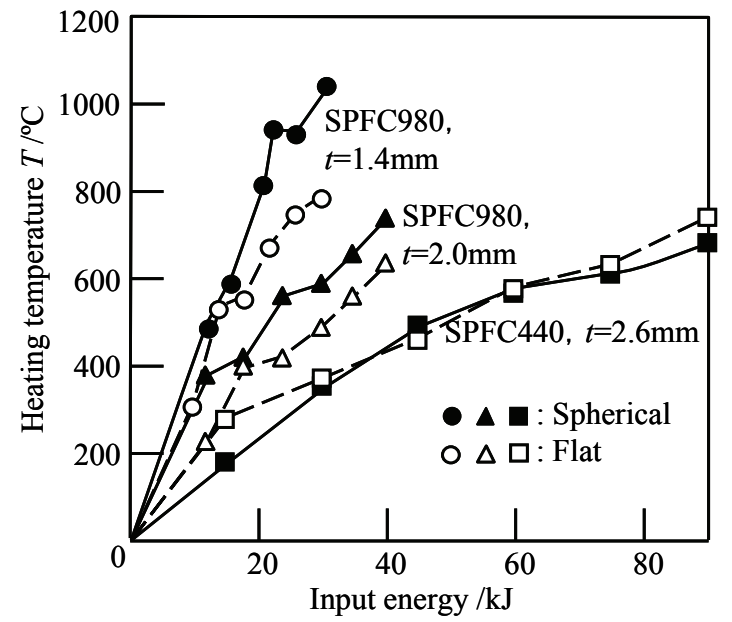

Fig. 9 Relationship between heating temperature and input energy for spherical and flat head electrode pins in sheet holder

\section{4. 局部通電加熱穴抜き加工}

\section{1 穴抜き加工条件}

局部通電加熱穴抜き加工装置を Fig. 10 に示す. 電極は Fig. 8 に示すものを用いた. 穴抜き加工には $800 \mathrm{kN}$ サーボ プレス（コマツ産機森）ＨCP3000）を用い，プレスは定電 流電源装置と同期しており，局部通電加熱後 0.2 秒後に穴 抜き加工ができる．パンチとダイスが鋼板に接触していな 
い状態で局部通電加熱を行い, 加熱後に鋼板を穴抜き加工 するため, パンチとダイスの熱影響は最小限になる. 穴抜 き荷重はパンチ上部に取り付けられたロードセルから測定 された. 厚さ $t=1.4 \mathrm{~mm}$ の SPFC980Y と $t=2.6 \mathrm{~mm}$ の SPFC440 を穴抜き加工し, クリアランスはせん断面比率が最大にな った板厚の $10.5 \%$ と 6\%をそれぞれ用いた. せん断領域加熱 温度は $T=600 \sim 1200^{\circ} \mathrm{C}$ であった.

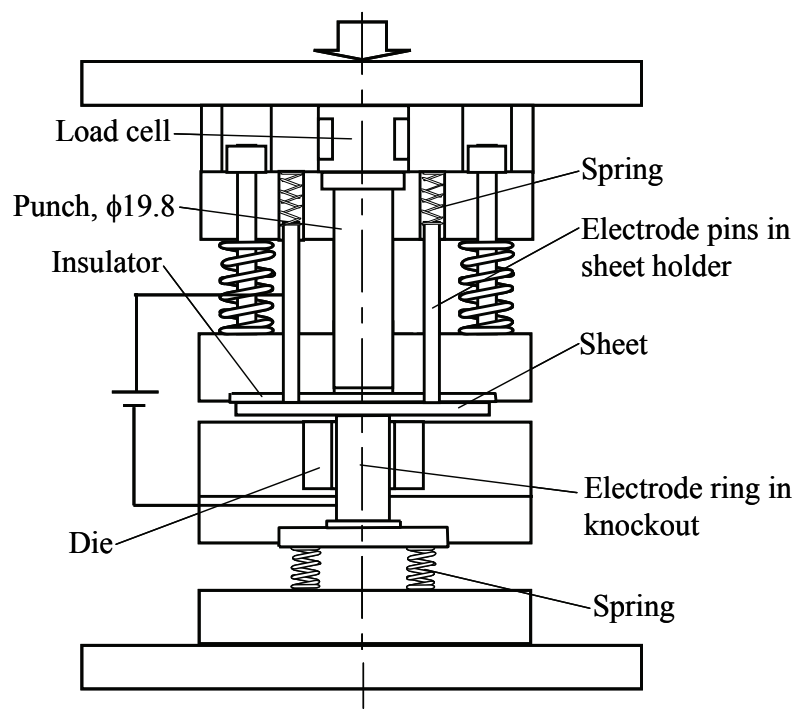

Fig. 10 Punching process of ultra high strength steel sheet using local resistance heating

\section{2 穴抜き加工結果}

SPFC980Y， $T=850^{\circ} \mathrm{C}$ における穴抜き加工された板材を Fig. 11 に示す. せん断領域付近がリング状に加熱されてお り，局部的に加熱されてせん断加工されている.
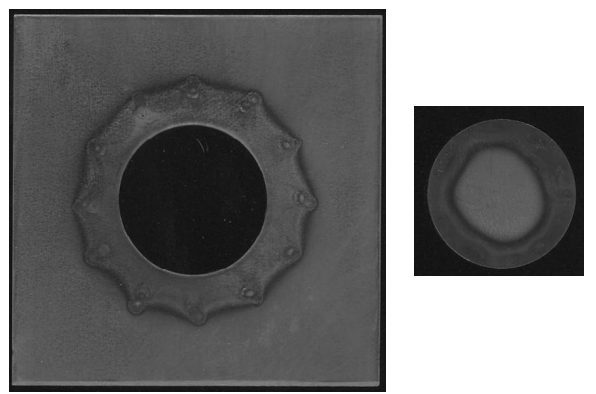

(a) Sheet holder side
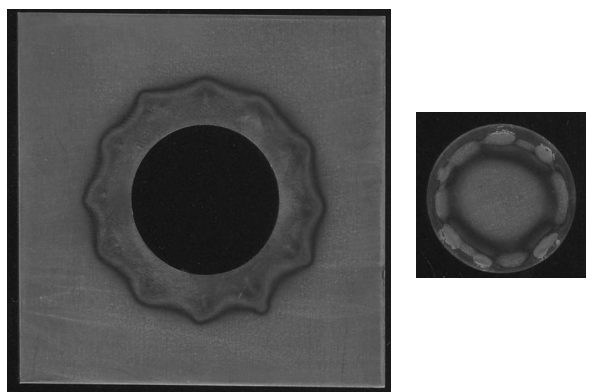

(b) Knockout side

Fig. 11 Punched sheet and blank for SPFC980Y and $T=850^{\circ} \mathrm{C}$

最大穴抜き荷重とせん断領域加熱温度 $T$ の関係を Fig. 12 に示す．加熱温度の上昇とともに最大穴抜き荷重は減少し
ており, $T=800^{\circ} \mathrm{C}$ において冷間加工の $1 / 5$ 程度の荷重にな っている.

SPFC980Y における穴抜き加工された切口の表面と断面 をFig. 13 に示す. 超高張力鋼板である SPFC980Y では, 冷 間加工において延性が低く, クラックが発生しやすく, 平 滑なせん断面は非常に少ないが，加熱温度の上昇とともに せん断面が増加している。

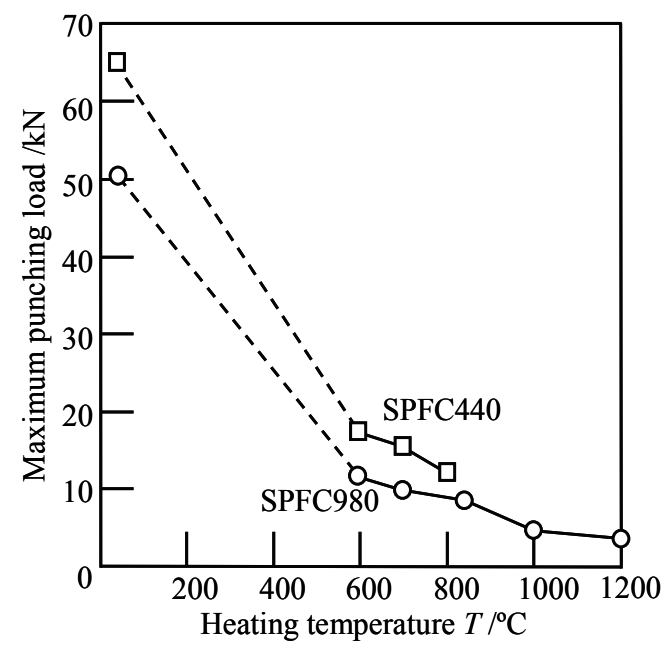

Fig. 12 Relationship between maximum punching load and heating temperature

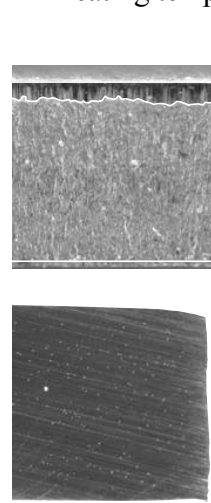

(a) $T=25^{\circ} \mathrm{C}$

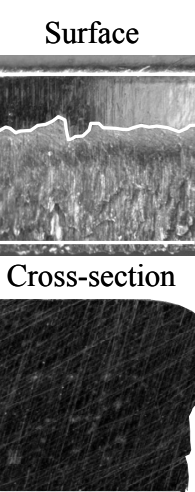

(b) $T=700^{\circ} \mathrm{C}$
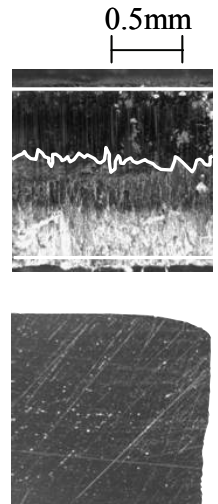

(c) $T=850^{\circ} \mathrm{C}$

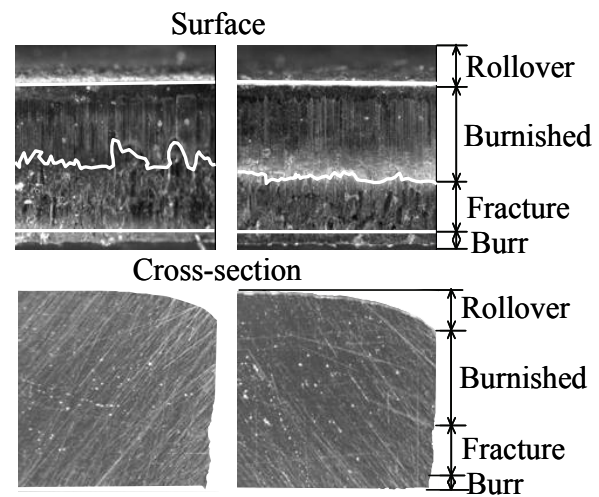

(d) $T=1000^{\circ} \mathrm{C}$

(e) $T=1200^{\circ} \mathrm{C}$

Fig. 13 Surfaces and cross-sections of sheared edges at different heating temperatures for SPFC980Y

穴抜き加工された切口面のだれ，せん断面，破断面，ば り構成比と加熱温度の関係を Fig. 14 に示す. 加熱温度の増 加とともに, だれ, せん断面, ばりは大きくなっているが, 破断面は減少している. 延性の低い超高張力鋼板において, 


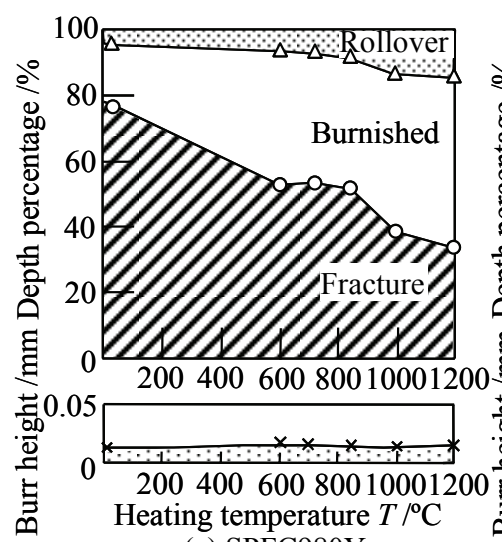

(a) SPFC980Y

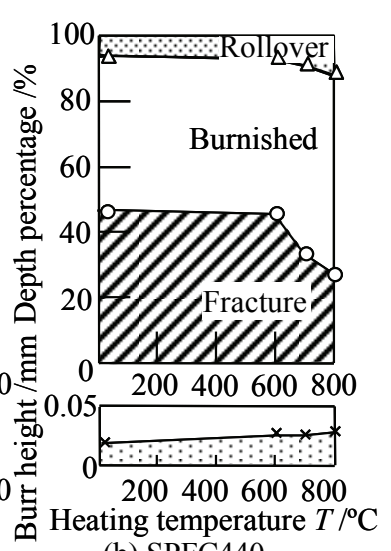

(b) SPFC 440
Fig. 14 Variations in depth percentages of burnished surface, fracture surface and rollover and burr height on sheared edge with heating temperature

切口面の表面性状は加熱によって大きく向上する.

SPFC980Yにおける切口面から $0.1 \mathrm{~mm}$ 離れた部分の板厚 方向硬さ分布を Fig. 15 に示す. $T=850^{\circ} \mathrm{C}$ 以上では, $300 \mathrm{HV} 0.05$ 程度である冷閒のものよりも硬さは 1.5 倍程度 大きくなっており，金型によって急冷されて切口面が焼入 れされている.

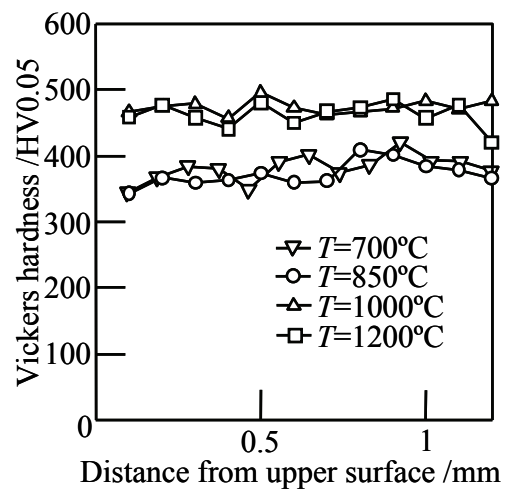

Fig. 15 Distributions of hardness in thickness direction at distance of $0.1 \mathrm{~mm}$ from sheared edges for SPFC980Y

SPFC980Yにおける穴直径と加熱温度の関係を Fig. 16 に 示す. 加熱によって膨張した状態で穴抜き加工されるため, 加熱温度とともに直径が少し大きくなる，延長上に電極ピ ンが位置する穴直径は, 電極ピン中間が延長上に位置する ものとほとんど同じ值であった.

SPFC980Y, $T=850^{\circ} \mathrm{C}$ における切口面と電極の間の組織の

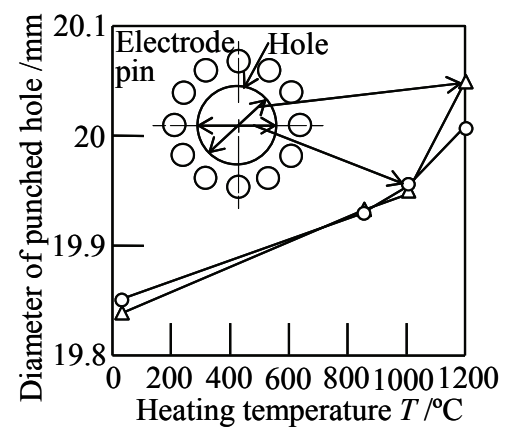

Fig. 16 Relationship between diameter of punched hole and heating temperature for SPFC980Y
分布を Fig. 17 に示す. 切口面付近では穴抜き加工によるメ タルフローが観察され, 切口面と電極直下はパンチと電極 によってそれぞれ急冷されてマルテンサイト組織が現れて おり，その中央部では焼入れはされていない.
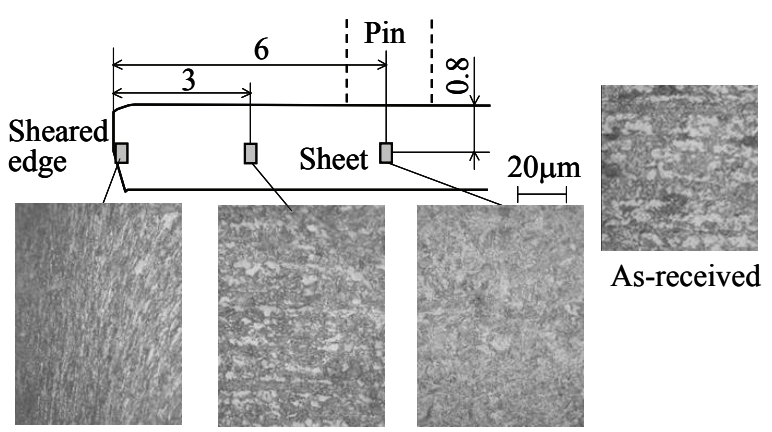

As-received

Fig. 17 Distributions of microstructure for SPFC980Y and $T=850^{\circ} \mathrm{C}$

\section{5. 結 言}

超高張力鋼板のせん断加工を容易にするために, せん断 領域を局部通電加熱してせん断加工を行った. 通電加熱に 適した電極の材質・形状を調べるとともに，超高張力鋼板 の局部通電加熱穴抜き加工を行い, 以下の知見を得た.

1) 板押えとノックアウト間で板材を通電し, ダイスとパン チは通電中板材と接触させなくして通電終了直後にせ ん断加工を行い, ダイスとパンチの加熱を防止できた.

2) バネを付けた電極ピンを用いることによって局部接触 を防止でき，リング状のせん断領域を加熱することが できた.

3) $\mathrm{Cu}-\mathrm{W}$ の電極ピンが一番少ない溶着を示した.

4) 局部通電加熱穴抜き加工を行い, $800^{\circ} \mathrm{C}$ の加熱温度にお いて冷間加工の $1 / 5$ 程度の荷重になった。

5) 加熱温度の上昇とともに, 高い表面性状であるせん断面 は増加した。

本研究の一部は, 平成 19 年度大澤科学技術振興財団研究 助成, 平成 21 年度科学研究費補助金基盤研究(B)によって 行われた。

\section{参 考 文 献}

1) 佐藤章仁 : 塑性と加工, 46-534 (2005), 548-551.

2) 杉山隆司 : 同上, 46-534 (2005), 552-555.

3) 柳生聖司 - 長井美憲 - 桑田尚：同上, 46-534 (2005), 651-655.

4) 小嶋啓達 : 同上, 46-534 (2005), 595-599.

5) Mori, K., Maki, S. \& Tanaka, Y.: CIRP Ann., 54-1 (2005), 209-212

6) Neugebauer, R., Altan, T., Geiger, M., Kleiner, M. \& Sterzing, A.: ibid., 55-2 (2006), 793-816.

7) 森謙一郎 - 牧清二郎 - 斉藤翔一 - 岸本信 - 林達志 - 奥 村俊彦 : 塑性と加工, 48-555 (2007), 318-322.

8) 森謙一郎 - 伊藤大介 : 同上, 50-577 (2009), 129-133.

9) 村川正夫 - 古閑伸裕 -大川陽康 - 西垣徳是 : 同上, 31-354 (1990), 924-928.

10) 森謙一郎・斉藤翔一・牧清二郎 - 岸本信 - 林達志 - 奥 村俊彦：同上, 49-564 (2008), 56-60. 